\title{
Project-Based Learning and its Impact on the Academic Performance of Middle School Students
}

\author{
Richard Eduardo Sánchez Bravo \\ Pontificia Universidad Católica del Ecuador, Manabí Headquarters, Chone, Ecuador \\ Corresponding author email: rsanchez9118@pucesm.edu.ec \\ Jorge Armando Zambrano Andrade \\ Pontificia Universidad Católica del Ecuador, Manabí Headquarters, Chone, Ecuador \\ Email: armando.zambrano@educacion.gob.ec \\ María Elizabeth Zambrano Cornejo \\ Pontificia Universidad Católica del Ecuador, Manabí Headquarters, Chone, Ecuador \\ Email: m_e.zambrano@educacion.gob.ec \\ Jaime Darío Santos Loor \\ Unidad Educativa Eugenio Espejo, Chone, Manabí, Ecuador \\ Email: jaime.santos@educacion.gob.ec
}

\begin{abstract}
The adoption of active methodologies in the teaching-learning process allows the main actors of education to transform the classroom into scenarios of real experiences of learners. This research aims to analyze the Project-Based Learning methodology and its impact on the academic performance of middle school students. In this research, several methods were applied, including the qualitative documentary bibliographic review, the inductive-deductive method, allowing to identify the characterization of project-based learning, in addition, the academic results of the students of basic secondary of the Educational Unit "Aurelio Salazar". As result, it was obtained that Project-Based Learning is an active methodology of current education where the teaching process is innovated, the academic performance of 62 students who attended the 2020-2021 school year was analyzed.
\end{abstract}

Keywords---academic performance, education, knowledge, methodology learning, project-based learning

\section{Introduction}

Education is in a transition stage where the traditional way of transmitting knowledge is lagging due to the adoption of new learning strategies. The Educational Units are implementing new educational methodologies in the classroom, which become innovative means to achieve the educational goal, this research was carried out in an educational unit located in the urban sector where the Project-Based Learning methodology was analyzed (ABP) and its impact on the academic performance of middle school students (Cheng et al., 2012; Moreira \& Rodríguez, 2020). Traditional learning methodologies are a linear process where the teacher is the main transmitter of knowledge within the classroom and the student is just a passive receiver listening to expositions and experiences of third parties, holding the textbook as the only available tool conditioned to memorize content. to excel in the final evaluation and this serves to give credit for the received learning (Muntaner et al., 2020).

Active methodologies allow teachers and students to build their knowledge inside and outside the classroom, awakening the interest in learning interactively with methods that allow the teaching-learning process to be dynamic, innovative, and meaningful, assuming that the new strategies are cognitive and constructive activities that allow to successfully achieve the educational objectives set (Meza, 2013). Project-based learning has a constructivist 
approach, encourages collaborative work from the planning stage to obtaining the final product, allowing the student to consider topics of interest to develop skills from problem-solving and their own experiences in the teachinglearning process, with the continuous accompaniment of teachers, parents, legal representatives, or other educational actors (Solís-Pinilla, 2021).

To achieve the generation of new cognitive, communicative, and emotional experiences, the ABP methodology requires the use of information and communication technologies (ICT) as a transcendental and innovative resource in the teaching-learning process (Ausín et al., 2016). The teacher becomes an innovative entity by using active methodologies and technological tools allowing the realization of structured, oriented, and formative activities, stimulating critical-constructive thinking in the student, in addition, these mergers of strategies allow to strengthen meaningful learning through experiences real acquired that arise in the projects (Nieto \& Martínez, 2021).

In the ABP methodology, the student is no longer just receptive, it is part of the planning of projects for the generation of new knowledge, allowing to devise activities that contribute to meaningful reflection through experience and innovative motivation (Botella Nicolás \& Ramos Ramos, 2020). The academic performance of students is a traditional way of verifying the knowledge acquired during a school period or in a certain period of study, which quantitatively shows the achievement of educational objectives at the end of the course, establishing the approval of this for the next phase. With the new methodologies, the knowledge acquired is evaluated at all times of the teaching-learning process (Rodríguez Pinto, 2019). In Ecuador, ABP methodologies have also been contributed, these have been introduced in class schools, in different areas both rural and urban areas, contributing to the knowledge of students (Matzumura Kasano et al., 2018), other authors have implemented other innovative techniques (Pachay López et al., 2020).

\section{Materials and Methods}

For the research, the qualitative method of documentary bibliographic review was applied, which allowed the search, analysis, and systematization of information that significantly contribute to investigative work, inductive-deductive, allowing to identify the characterization of project-based learning, in addition, the quantitative one to analyze the academic results of the students of basic secondary of the Educational Unit "Aurelio Salazar" who attended the school year 2020-2021.

\section{Results and Discussions}

For the development of the investigative work, documented information from different authors was analyzed, especially on the following topics: traditional education, active learning methodologies, Project-Based Learning, new teaching strategies, different perspectives of the main actors of a classroom, and the steps to create a project with the ABP methodology (Guo et al., 2020; Han et al., 2016; Arjawa et al., 2017). Traditional learning consists of the teacher being the center of the class exposing the selected topic or according to the previously elaborated curriculum to ensure that the student achieves the planned learning by attending passively without interacting dynamically and taking the necessary notes for later at home transcribe or carry out the proposed task, in addition to completing this traditional strategy the teacher needs to evaluate the knowledge through a final evaluation in a time determined by the educational regulations, for which the student must memorize content (Polanco et al., 2004). Figure 1. Traditional learning explicitly shows the meaning of traditional learning, the role of the teacher and the student.

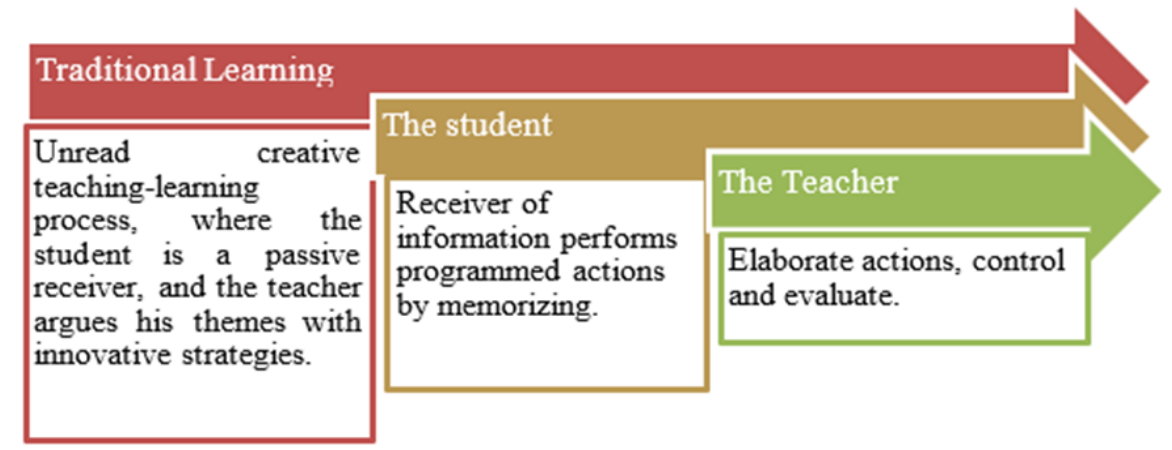

Figure 1. Traditional learning

Source: (León et al., 2019) 
For years the educational system has been proposing different methodologies that allow the activation of significant knowledge in students, training, and turning the teacher into a guide (Chu et al., 2011; Calderhead, 1991). The teacher's accompaniment is essential to achieve educational objectives through the application of innovative methodologies that motivate and participate in the student. Active methodologies link various learning proposals that are based on activities that make the student investigate, reflect and learn by experimenting (Espinoza, 2020). In Figure 2. Types of methodologies, the methodologies that are mostly used today in the teaching-learning process are appreciated.

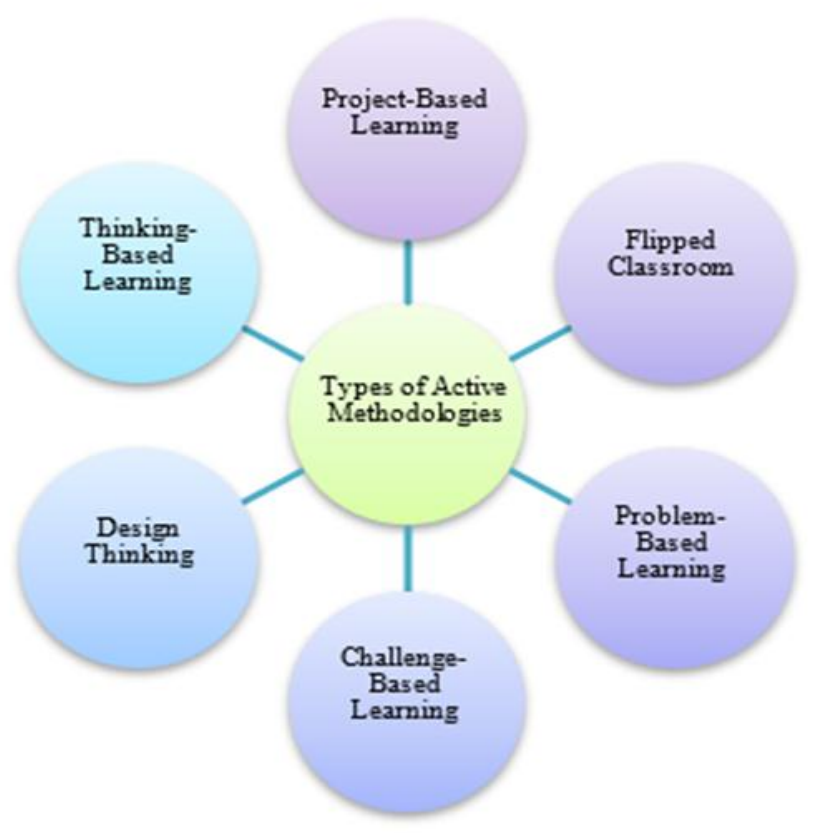

Figure 2. Types of active methodologies Source: (Espinoza, 2020)

\section{Inverted classroom}

Innovative methodology that consists of using the environments where the student operates such as the home and the classroom, with the application of this method the teacher seeks to motivate and awaken the student's interest in previously learning from home and sharing the experiences in the classroom (Cantuña Avila \& Cañar Tapia, 2020).

\section{Problem-based learning}

An active tool where the student learns individually or in a team, being this the main actor in the learning process discovering and learning new knowledge developing critical and reflective skills (Bermúdez Mendieta, 2021).

\section{Challenge-based learning}

Active and innovative learning strategy that contributes to meaningful student learning through challenges, using the elements of motivation, emotion, and cognition (Rodríguez et al., 2021).

\section{Design thinking}

The active methodology focused on action, that is, from theoretical knowledge to practical experiences where new solutions are designed to real everyday problems of the environment or the community (Latorre-Cosculluela et al., 2020). 


\section{Thought-based learning}

It is an active methodology that allows the generation and development of critical and creative thoughts through practical procedures, it contributes to the development of student's skills and abilities (Ruiz, 2018).

\section{Project-based learning (PBL)}

It is an active methodology adopted in current education innovating the traditional teaching-learning process, one purpose of this method is the development and presentation of a final product, promoting team and autonomous work (Gómez-Pablos et al., 2017).

In the "Aurelio Salazar" Educational Unit, the teamwork carried out by the teaching staff and other educational actors was observed in the planning, execution, and evaluation of interdisciplinary projects based on the PBL methodology, adopted as an innovative strategy to achieve learning significance in learners (de la Puente Pacheco et al., 2020; Bacilio, 2021). The PBL is made up of two projects: humanistic and scientific, each of them includes subjects with activities that will contribute to the achievement of the final product, as shown in figure 3, Inputs that make up the PBL in the teaching-learning process.

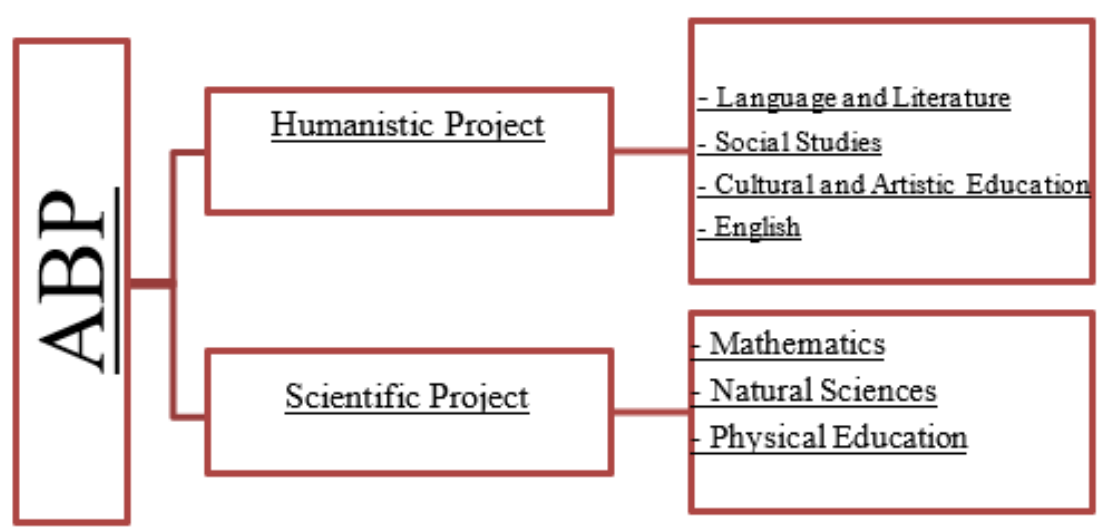

Figure 3. Subjects that make up the PBL

It is stated that the teaching team selected the steps that allow them to build both humanistic and scientific projects each time, as shown in figure 4 . Phases of project construction:

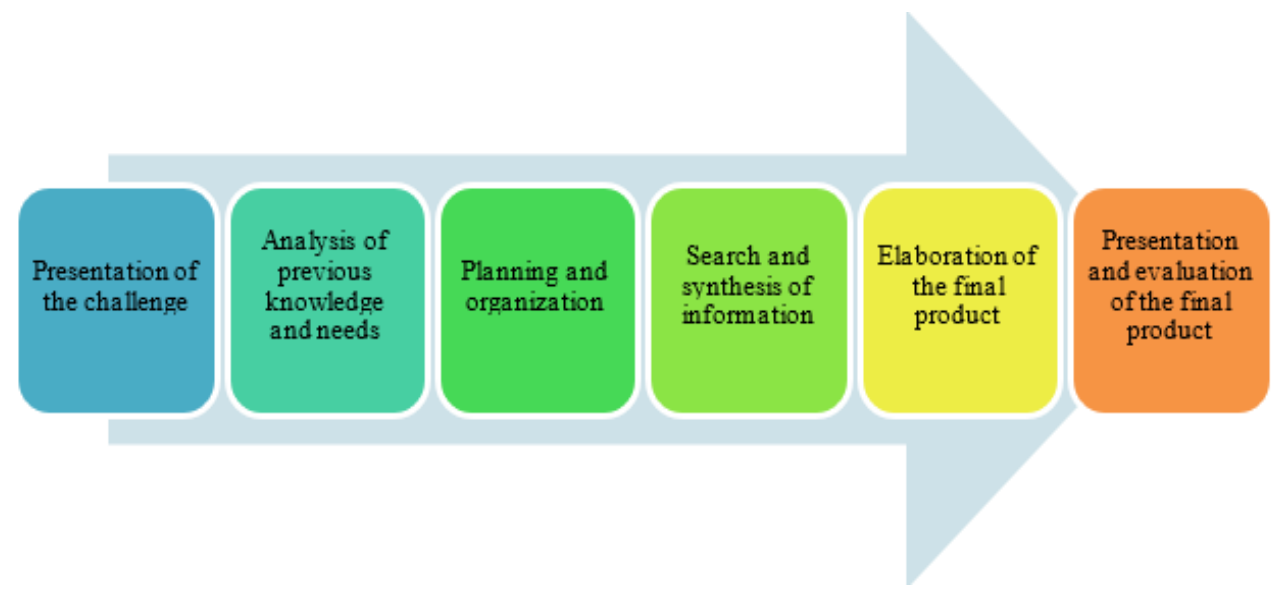

Figure 4. Phases for the construction of projects

Source: (Nieto \& Martínez, 2021) 


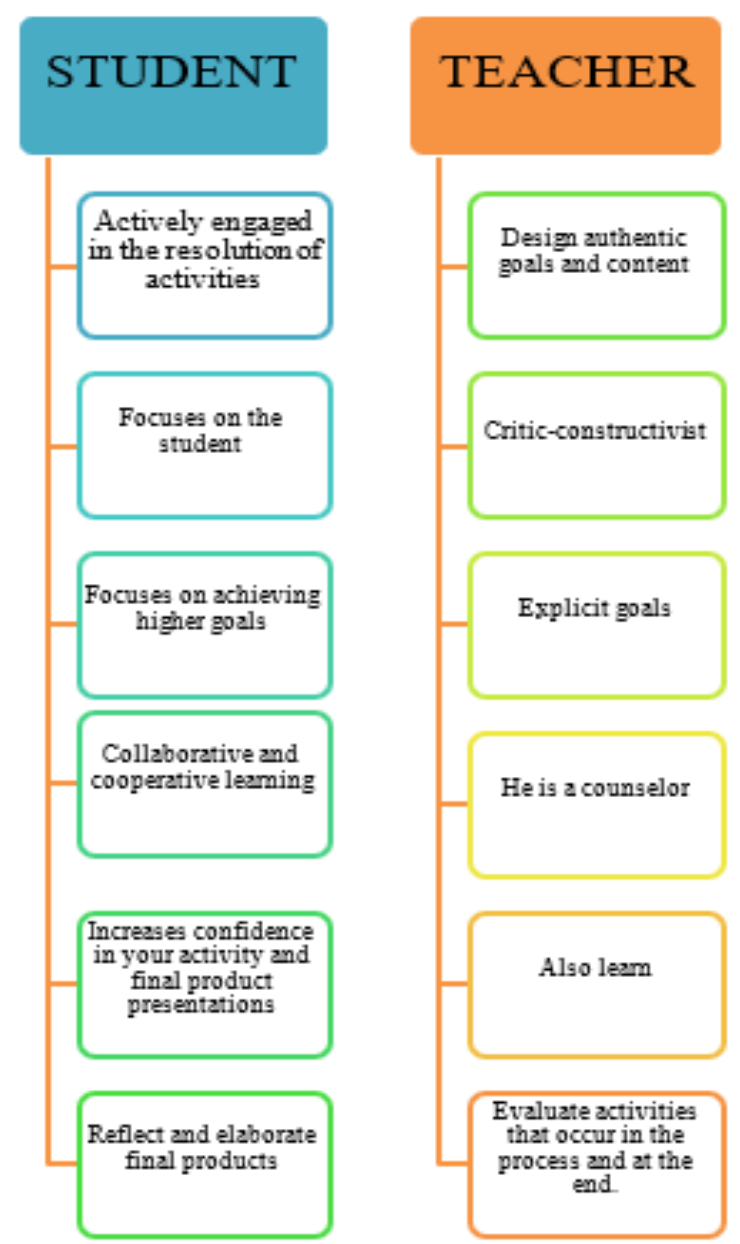

Figure 5. Student and teacher perspective Source: (Martí et al., 2010)

In the research, the analysis of academic performance was carried out of 62 students who attended the 2020-2021 school year in basic medium to know the incidence of the ABP methodology applied in this school period, data that is presented in table 2: Academic performance:

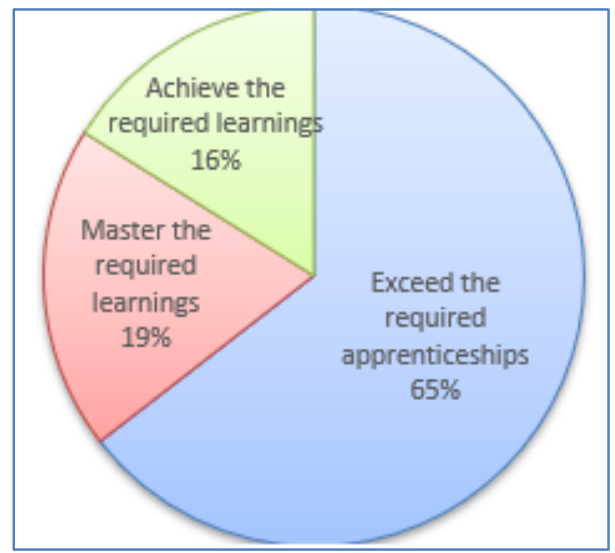

Figure 6. Academic performance of higher basic students 
The Educational unit "Aurelio Salazar" implements the methodology of project-based learning (Efstratia, 2014; Ergül \& Kargin, 2014). According to the information in its files, an analysis of the academic performance of Basic School students was carried out. Average, the results indicate that $65 \%$ of the students pass the required learning, that is, they obtained grades of 10 , while $19 \%$ dominate the required learning, obtaining grades between 9 and $16 \%$ of them reached the required learning grades that They comprise between 7 and 8 , this new experience has allowed most of the students to master the required learning, however, there is a small group that due to environmental situations did not manage to master the learning (Lasauskiene \& Rauduvaite, 2015; Chen \& Yang, 2019).

\section{Conclusion}

In the current educational process, several active methodologies are applied, including PBL, a dynamic and innovative learning method that allows the design of activities so that the student can develop skills autonomously, critically, and creatively, accompanied and guided by the teacher. It was applied in the "Aurelio Salazar" Educational Unit, showing that it effectively affects the academic performance of middle school students, managing to develop new experiences evidencing them in portfolios and exhibitions each time, this method allows evaluation through the application of rubrics previously designed by the management team.

\section{References}

Arjawa, A. A. G. P., Sariyasa, .-., \& Suweken, G. (2017). Developing instructional multimedia for teaching line and angle to the seventh grade students of junior high school. International Research Journal of Engineering, IT \& Scientific Research, 3(5), 66-75. Retrieved from https://sloap.org/journals/index.php/irjeis/article/view/577

Ausín, V., Abella, V., Delgado, V., \& Hortigüela, D. (2016). Project-based learning through ICT An experience of teaching innovation from university classrooms. Formación universitaria, 9(3).

Bacilio, GMH (2021). ICT-mediated project-based learning to develop mathematical competencies in high school students. Latin Science Multidisciplinary Scientific Journal , 5 (4), 5617-5646.

Bermúdez Mendieta, J. (2021). Problem-based learning to improve critical thinking: systematic review.

Botella Nicolás, A. M., \& Ramos Ramos, P. (2020). Motivation and Project Based Learning: an Action Research in Secondary School. REMIE-Multidisciplinary Journal of Educational Research, 10(3).

Calderhead, J. (1991). The nature and growth of knowledge in student teaching. Teaching and teacher education, 7(5-6), 531-535. https://doi.org/10.1016/0742-051X(91)90047-S

Cantuña Avila, AA, \& Cañar Tapia, CE (2020). Systematic review of the flipped classroom in Ecuador: approach to the state of the art. Pedagogical Studies (Valdivia), 46 (3), 45-58.

Chen, C. H., \& Yang, Y. C. (2019). Revisiting the effects of project-based learning on students' academic achievement: A meta-analysis investigating moderators. Educational Research Review, 26, 71-81. https://doi.org/10.1016/j.edurev.2018.11.001

Cheng, M. M., Tang, S. Y., \& Cheng, A. Y. (2012). Practicalising theoretical knowledge in student teachers' professional learning in initial teacher education. Teaching and Teacher Education, 28(6), 781-790. https://doi.org/10.1016/j.tate.2012.02.008

Chu, S. K. W., Tse, S. K., \& Chow, K. (2011). Using collaborative teaching and inquiry project-based learning to help primary school students develop information literacy and information skills. Library \& Information Science Research, 33(2), 132-143. https://doi.org/10.1016/j.lisr.2010.07.017

de la Puente Pacheco, MA, de Oro Aguado, CM, \& Lugo Arias, ER (2020). Student perception of the effectiveness of project-based learning in health in the Colombian Caribbean. Higher Medical Education, 34 (1).

Efstratia, D. (2014). Experiential education through project based learning. Procedia-social and behavioral sciences, 152, 1256-1260. https://doi.org/10.1016/j.sbspro.2014.09.362

Ergül, N. R., \& Kargın, E. K. (2014). The effect of project based learning on students' science success. ProcediaSocial and Behavioral Sciences, 136, 537-541. https://doi.org/10.1016/j.sbspro.2014.05.371

Espinoza, JJR (2020). Active methodologies, the key to changing schools and their application in times of pandemic. INNOVA Research Journal , 5 (3), 2.

Gómez-Pablos, V. B., del Pozo, M. M., \& Muñoz-Repiso, A. G. V. (2017). Project-based learning (PBL) through the incorporation of digital technologies: An evaluation based on the experience of serving teachers. Computers in Human Behavior, 68, 501-512. https://doi.org/10.1016/j.chb.2016.11.056 
Guo, P., Saab, N., Post, L. S., \& Admiraal, W. (2020). A review of project-based learning in higher education: Student outcomes and measures. International Journal of Educational Research, 102, 101586. https://doi.org/10.1016/j.ijer.2020.101586

Han, S., Capraro, R. M., \& Capraro, M. M. (2016). How science, technology, engineering, and mathematics project based learning affects high-need students in the US. Learning and Individual Differences, 51, 157-166. https://doi.org/10.1016/j.lindif.2016.08.045

Lasauskiene, J., \& Rauduvaite, A. (2015). Project-based learning at university: Teaching experiences of lecturers. Procedia-Social and Behavioral Sciences, 197, 788-792. https://doi.org/10.1016/j.sbspro.2015.07.182

Latorre-Cosculluela, C., Vázquez-Toledo, S., Rodríguez-Martínez, A., \& Liesa-Orús, M. (2020). Design Thinking: creativity and critical thinking in the university. Electronic journal of educational research, 22 .

León, WM, Carranza, LS, \& Sánchez, CP (2019). Project-based learning: Reality and perspectives. Journal of Science and Research: Science and Research Magazine. ISSN 2528-8083 , 4 (4), 22-33.

Martí, JA, Heydrich, M., Rojas, M., \& Hernández, A. (2010). Project-based learning: an experience of teaching innovation. EAFIT University Magazine , 46 (158), 11-21.

Matzumura Kasano, JP, Gutiérrez-Crespo, H., Pastor-García, C., Zamudio-Eslava, LA, \& Ruiz-Arias, RA (2018, October). Active methodology and learning styles in the teaching process in the research methodology course of a faculty of health sciences. In Annals of the Faculty of Medicine (Vol. 79, No. 4, pp. 293-300). UNMSM. School of Medicine.

Meza, A. (2013). Learning strategies. Definitions, classifications and measurement instruments. Purposes and Representations, 1 (2), 193-213. National University of San Marcos, Lima, Peru .

Moreira, M. P. S. ., \& Rodríguez, M. A. Y. . (2020). Impact on high school students by the application of innovative methods in virtual education. International Research Journal of Engineering, IT \& Scientific Research, 6(6), 1-9. https://doi.org/10.21744/irjeis.v6n6.1015

Muntaner Guasp, JJ, Pinya Medina, C., \& Mut Amengual, B. (2020). The impact of active methodologies in academic results: A case study. Teachers , 24 (1), 96-114.

Nieto, C., \& Martínez, P. (2021). Characterization of project-based learning to strengthen entrepreneurial skills. Knowledge Pole, 6 (3), 2482-2499.

Pachay López, MJ, Rodríguez Gámez, M., \& Vera Pachay, LM (2020). Cooperative learning an innovative active methodology. Atlante Cuadernos de Educación y Desarrollo , (August).

Polanco*, R., Calderón, P., \& Delgado, F. (2004). Effects of a problem-based learning program on engineering students' academic achievements in a Mexican university. Innovations in Education and Teaching International, 41(2), 145-155.

Rodríguez Pinto, BL (2019). The methodology of project-based learning and school performance in the area of Natural Sciences, of children in the sixth year of Basic General Education of the Educational Unit "San Antonio de Padua", Quito canton, Pichincha province (Bachelor's thesis, Universidad Tècnica de Ambato. Faculty of Human Sciences and Education. Basic Education Degree).

Rodríguez-Borges, CG, Pérez-Rodríguez, JA, Bracho-Rodríguez, AM, Cuenca-Álava, LA, \& Henríquez-Coronel, MA (2021). Challenge-Based Learning as a teaching-learning strategy of the subject resistance of materials. Science Domain , 7 (3), 82-97.

Ruiz, M. (2018). Thought-based learning: its application in the teaching of criminal law. Journal of Education and Law, 1 (18), 54-60.

Solís-Pinilla, J. (2021). Project-based learning: a didactic proposal for socio-emotional development. Educational Knowledge Magazine , (6), 76-94. 